\title{
THE GLASGOW UNIVERSITY EXPLORATION SOCIETY EXPEDITION TO MINGULAY
}

\author{
By J. F. ROBERTSON, J. B. RANKIN \\ and $D_{R}$. D. R. BOWES \\ University of Glasgow
}

AND

\author{
A. M. HOPGOOD \\ University of St. Andrews
}

A

GLASGOW University Exploration Society expedition to the uninhabited Island of Mingulay (Nat. Grid NL 056783), some twolvo miles south of Barra in the Outer Hubrides, was made during June 21-July 14, under the leadership of Mr. J. F. Robertson. The Island is essentially mado up of rocks of the Lowisian complex ${ }^{1}$ and the geological investigations, undertaken by six of the expedition members under the direction of Dr. D. R. Bowes and $\mathrm{M}_{\mathrm{r}}$. A. M. Hopgood, are a continuation of Lewisian investigations being carried out in the Depart. monts of Geology of the University of Glasgow and the University of St. Andrews. Topographically the dominarit features of the island are the sheur eliffs, some more than $700 \mathrm{ft}$. high, on the western seaboard, and a large, sheltered eastward-facing glacially-carved amphitheatre which rises from a sandy bay on the eastorn suaboard. A crofting settlement, almost completely abandoned in 1909, is situated in the lower parts of this amphitheatre largely on superficial deposits of boulder clay and sand. This 'fossilized' sottlement, which has remained wellpreserved by virtue of its isolation, was investigated under tho direction of Mr. J. F. Robertson and Mr. J. B. Rankin as part of the crofting investigations being carried out by the Departments of Geography and Archæology of the University of Glasgow.

The Lewisian rocks aro dominantly bainded gneisses of intermediato to acid composition. They show evidence of metamorphic reconstitution at hornblende granulite facies, and subsequent retrogressive effects, and are injected by many structurally controlled pegmatite veins. The effects of at least five periods of folding and associated deformation are displayed. In addition there is evidence of two periods of pseudotachylite development, one within the Lewisian sequence and the other associated with the Hebridean Thrust. In summary the geological sequence of events is:

(1) The formation of the prominent banding, associated with tight isoclinal folding of lithological layers, tectonic disruption and metamorphic reconstitution at hornblende granulite facies. Strong linear and planar elements developed with mineral growth axial plane to the fold structures. The first prominent elements of rock microfabric were formed at this stage.

(2) The development of asymmetrical folds which fold the banding. The fold axes plunge gently north while the axial planes trend approximately north-west-south-east and dip in a north-easterly direction at a moderately steep angle. The dip of the north-eastern limb is consistently much less than that of the south-western limb which is commonly near vertical or overturned. A secondary foliation is developed parallel to the axial plane. The largest folds observed are of this typo and they control the gross attitude of the banding. Quartzofelspathic pegmatitic material developed and its upriso was controlled by the axial planes of these folds.

(3) Pseudotachylite was formed and injects gneisses and pegmatites. Bands of pseudotachylite breccia trend east-north-east-west-south-west and dip toward the south-south-east at approximately $30^{\circ}$.

(4) Open folding with much small-scale crenulation and the development of axial plane cleavage. Fold axes plunge gently towards the south-east and axial planes dip at a moderately steep angle to the south-west.

(5) Folding of variable intensity on approximately cast-west trending axes which plunge gently eastwards.
Interfuronce structures resulting from the effects of these folds on the asymmetrical folds are common and much of the variation in attitude of the lithological layering is the rusult of this interferunee. The most common and the largest pegmatitic veins trund cast-west and are emplaced parallel to the axial planes of these folds.

(6) Variable, very opon folding with near horizontal axes generally tronding betwoen north-north-east and eastnorth-cest.

(7) Thrusting, dislocation and pseudotachylite formation associated with the development of the Hebridean Thrust.

(8) Emplacement of dolerite dykes (of presumed Tertiary age).

Events 1-6 are considered to ropresent the Lewisian history of the rocks and they correspond, both individually and in sequence, with Lewisian events shown by the rocks of Barra investigated by one of us (A. M. H.). There is also considerable similarity to the Lewisian rocks of the mainland, particularly in the vicinity of Gairloch, investigated by one of us (D. R. B.), but correlation at this stage, in the absence of absolute age dates, is considered prematuro.

The main settlement, which was surveyed by plane table at a scale of $1: 500$, consisted of approximately thirty crofts. It was located on the seaward side of the main track joining the school and St. Columba's Chapel, both of which were set apart from the rest of the village. The quality of the dry stone masonry of the croft houses was generally good, entire walls being intact in somo cases, some with stones up to three-quarters of a ton. All tho croft houses were roofless and most were approximately $30 \mathrm{ft}$. long, $15 \mathrm{ft}$. wide and $5 \mathrm{ft}$. high (internal measuremonts) with doorways $4 \mathrm{ft}$. 6 in. high by $2 \mathrm{ft}$. 6 in. wide. Both doorways and windows were topped by stone lintels. The walls, which consisted of inner and outer stone sholls with rubble between, were approximately $4 \mathrm{ft}$. thick and generally rounded at the comers. Most of the croft houses had a fireplace and chimney in the end wall, and, with the exception of two that were gabled, the houses were hip-ended. The chief area of crofting land, surveyed at a scale of $1: 2,500$, was located on the landward side of the main track on the southern flanks of the amphitheatre. Elongate rectangular croft strips extended down the well-drained slopes from the Lewisian outerops to one of the small streams cut in the boulder clay. Drystone dykes, some in very good condition, bounded the strips of land-good quality pasture broken by rock outcrops towards the hoad-dyke. The remains of the smaller crofting settlement at Skipsdale, in the south-eastern part of the island, were also investigated.

The expedition could not havo been arranged without the generous financial assistance of the University Court of the University of Glasgow, the Carnegie Trust for the Universities of Scotland and the Royal Scottish Geographical Society. Grateful acknowledgment of assistance is also made to Kodak, Ltd., Hanimex (U.K.), Ltd., the Northern Lighthouse Board, the keepers of Barra Head Lighthouse, the Invernoss Education Committen, our many kind friends in Castlebay, Barra, and Prof. Ronald Miller, Dr. J. B. Caird and Mr. ( $x$. Petrie of the Department of Geography, and Dr. H. Fairhurst of the Department of Archæology, University of Glasgow.

'Jehu, T. J., and Craig, R. M., Trans. Roy. Soc. Edin., 53, 419 (1923). 